* Corresponding author

Phone +421556022716

E-mail address:miroslav.badida@tuke.sk

(Miroslav Badida, Dr.h.c., prof., Ing., PhD.)

Article information

Article history: AMS-Volume15-No.3-00114-11

Received 23 March 2011

Accepted 26 May 2011

\section{Research of Selected Acoustic Descriptors of Two-Layer Sandwich Absorbers}

\author{
Miroslav Badida*, Ladislav Bartko, Ervin Lumnitzer, Róbert Szabó \\ Department of Environmentalistics, Faculty of Mechanical Engineering, P. Komenského 5, 04200 Košice, Slovak Republic
}

\section{BIOGRAPHICAL NOTES}

Miroslav Badida, Dr.h.c. prof. Ing. PhD. He is a graduate of Mechanical Faculty of Technical University of Košice. His scientific and research work focuses on the field of environmental engineering. An accent is put on the issue of environmental management systems, ecologization of products and their production and life cycle analysis of products. Lately his attention is paid on research in the field of physical factors of working and living environment.

Ladislav Bartko, Ing. Born in 1975, studied at the Faculty of Metallurgy of the Technical University in Košice. After his graduation from the Technical University, he took up the job of a computer network administrator at the company TATRY Ltd. In 2006 he started his doctoral (Ph.D.) study at the Faculty of Mechanical Engineering of the Technical University in Košice, in the field of study (discipline) of Environmental Engineering. Since 2009 he has been employed as a scientific \& research fellow worker at the Faculty of Mechanical Engineering of the Technical University in Košice at the Department of Environmental Engineering. He has been participating in solutions of a number of scientific $\&$ research projects. He is the au-thor and co-author of papers published at conferences in this country and abroad.

Ervin Lumnitzer, prof. Ing. PhD. He is graduated at Technical University of Košice in the field of "Robototechniques" in 1985. In 1995 he defended his dissertation thesis in field of "Mechanical Technologies" and in 2002 habilitated in the field of "Automation and Control". Nowadays he works as a university teacher. He is the head of the Environmental Engineering Department, authorized person for noise measurements in living and working environment, referee of bachelor stud ies in field of Environmental Management, chairman and also member of board of state examiners. Lately he is focused on the field of noise measurements and assessment, protection against industrial noise, noise mapping, noise visualization, assessment of the working environment quality.

Róbert Szabó, Ing. (1956) is a graduate of Mechanical Faculty of Technical University of Košice. His scientific and research work focuses on the field of environmental engineering. Lately his attention is paid on research in the field of factors of working and living environment. Currently he works at the ministry of education, science, research and sport as the director of the department of implementation of state support for research and development.

\section{KEY WORDS}

Environmental Noise, Transportation, Noise Wall, Sound Absorption Coefficient, Sound Transmission Loss, Absorber, Sandwich Absorber 


\section{ABSTRACT}

In spite of existing European and national legislation aimed at noise abatement, public interest and concern about noise are high. The EU Directive 70/157/EEC [13] for setting and controlling environmental noise is aimed at creating less noisy and more pleasant environment for European residents within "Sustainable Development in Europe". The authors are presenting a methodology for measuring selected acoustic descriptors (sound absorption coefficient and sound transmission loss) for acoustic materials, which are currently in process of development. Emphasis is put on sandwich structures of absorbers. Verification results of the proposed methodology are presented.

\section{Introduction}

In spite of existing European and national legislation, aimed at noise abatement, public interest and concern about noise are high. Directive of EU 70/157/EEC [13] for setting and controlling environmental noise is aimed at creating less noisy and more pleasant environment for European residents within "Sustainable Development in Europe".

Harmful effects of environmental noise are various and they can be produced in various ways. They can be categorised into three main categories: effects influencing health, impacts on quality of life and financial implications on affected persons.

In the European Union, about 80 million persons are exposed to high noise levels, which are unacceptable or result in sleep disorders and other undesirable influences. There are approximately 170 million people living in the so-called "grey regions", where noise is very annoying.

Transportation causes the main problem in the sphere of noise. In Europe, the first limits of protection against noise were specified for transportation. In this respect, the most important directive is 70/157/EEC [13], limiting noise for vehicles. The EU has only recently started to regulate noise emissions from railway transportation (2002). Limits for air transport are specified mainly at international levels ICAO (International Civil Aviation Organization).

Noise protection measures for reducing the effect of noise caused by transportation (road, railway and air transport) can be passive and active. Active measures try to prevent the origination of noise, while passive measures are adopted only then, when noise arises. Passive noise protection measures can be divided into two groups, namely: measures preventing acoustic noise propagation (noise barriers and/or walls, noise protection embankments and the like) [7].

Attention is paid to the design process and materials used for construction of noise walls and to their properties. The authors have focussed their attention on the research of new acoustic materials made on the basis of recycled raw materials and applicable for the structures of sandwich absorbers (two-layer and multiple-layer absorbers).

The paper presents a proposed methodology for measuring selected acoustic descriptors (the sound absorption coefficient $a$ and the sound transmission loss TL) [1].

\section{Proposal of Methodology for Measuring Selected Acoustic Descriptors of Acoustic Materials, which are Currently in Process of Development}

Out of several possible acoustic descriptors, the authors have focused their attention on the two following descriptors:

\section{- sound absorption coefficient (a), - transmission loss (TL).}

For measuring the sound absorption coefficient (a) and the transmission loss ( $\mathrm{TL}$ ) there are two theoretically available methods, namely: the method of standing wave ratio and the method of transfer function. The authors have used in their work the method of transfer function [9]. This method can be used for measuring the sound absorption coefficient, the reflection factor, the normal imped-

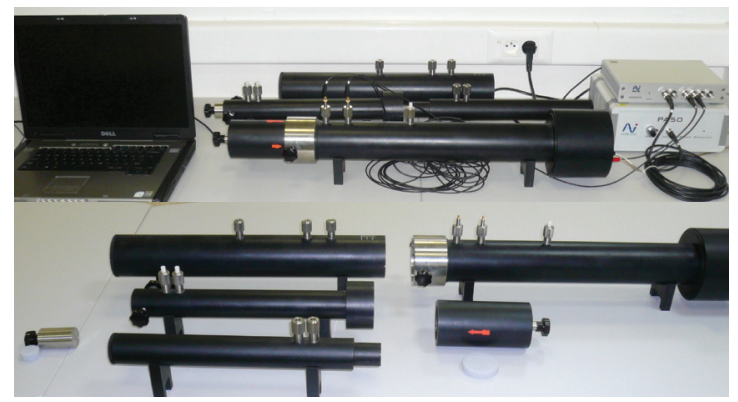

Fig. 1: The Impedance tube [1].

ance and the normal admittance. Based on this method is the impedance tube (Fig. 1).

The proposed methodology of measurement in- 
cludes the use of the impedance tube, two positions of positioning the microphones and the system of numerical frequency analysis for determining the sound absorption coefficient of sound absorbers for normal incidence of sound. It can also be applied for determining acoustic surface impedance or acoustic surface admittance for sound absorbing materials, due to the fact that the impedance ratios of sound absorbing materials are proportional to their physical properties, such as airflow resistance, porosity, elasticity and density.

This test method is similar to the test method specified in STN EN ISO 10534-1 [8] in terms of using an impedance tube with a sound source connected to one of its ends and a test specimen mounted into the tube at its other end. However, the actual test method is different. In this test method the plane waves are generated in the tube by the sound source and the decomposition of the interference field is achieved by measuring acoustic pressures in two fixed positions of microphones mounted on the wall of the tube or by a microphone shifted in the tube and the subsequent calculation of the complex acoustic transfer function, by absorption at normal incidence and by impedance ratios of the acoustic material. This test method is designated to provide an alternative method of measurement, in general much faster than that included in STN EN ISO 10534-1[8]. The proposal of methodology for measuring selected acoustic descriptors by using an impedance tube and by applying the method of transfer function is presented in Figs. 2, 3, 4 and 5.

\section{Verification of the Proposed Methodology for Measuring Acoustic Descriptors for Acoustic Materials, which are Currently in Process of Development}

The proposed methodology of measurement was verified by measuring selected acoustic descriptors, namely: the sound absorption coefficient (a) and the transmission loss ( $T L$ ) for the materials, which are currently in process of development.

\subsection{Instruments, Software and other Equipment}

The system for measuring the sound absorption coefficient (a) (for the frequency bands of $100 \mathrm{~Hz}$ to $800 \mathrm{~Hz}$ and $400 \mathrm{~Hz}$ to $2500 \mathrm{~Hz}$, respectively) is shown in Fig. 6. It is comprised of a tube with inner diameter of $60 \mathrm{~mm}$ - SW060-L and of a holder of the tested sample with inner diameter of $60 \mathrm{~mm}$ - SW060-S.

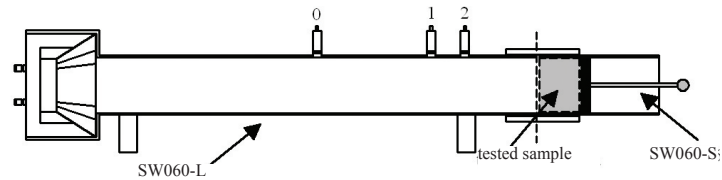

Legend: 0,1,2 mounting sockets for microphones

Fig. 6: The system for measuring the sound absorption coefficient (100 Hz to $800 \mathrm{~Hz}$ and $400 \mathrm{~Hz}$ to $2500 \mathrm{~Hz}$, respectively) [1].

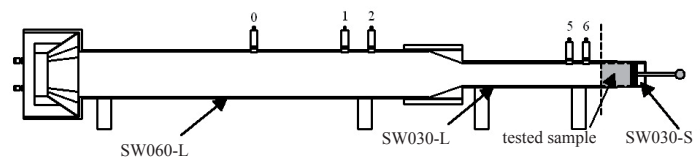

Legend: 0, 1, 2, 5, 6 mounting sockets for microphones

Fig. 7: The system for measuring the sound absorption coefficient (800 Hz to $6300 \mathrm{~Hz}$ ) [1].

The system for measuring the sound absorption coefficient (a) (for the frequency bands of $800 \mathrm{~Hz}$ to $6300 \mathrm{~Hz}$ ) is shown in Fig. 7. It is comprised of a tube with inner diameter of $60 \mathrm{~mm}$ - SW060-L, of a tube with inner diameter of $30 \mathrm{~mm}$ - SW030-L and of a holder of the tested sample with inner diameter of $30 \mathrm{~mm}$ - SW030-S.

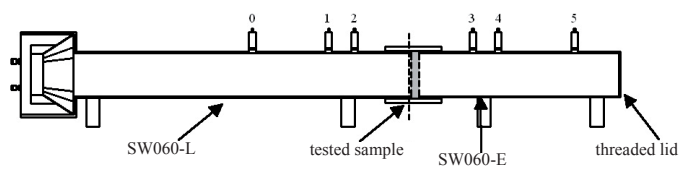

Legend: 0, 1, 2, 3, 4, 5 mounting sockets for microphones

Fig. 8: The system for measuring the transmission loss TL ( $100 \mathrm{~Hz}$ to $800 \mathrm{~Hz}$ and $400 \mathrm{~Hz}$ to $2500 \mathrm{~Hz}$, respectively) [1].

The system for measuring the transmission loss (TL) (for the frequency bands of $100 \mathrm{~Hz}$ to $800 \mathrm{~Hz}$ and $400 \mathrm{~Hz}$ to $2500 \mathrm{~Hz}$, respectively) is shown in Fig. 8. It is comprised of a tube with inner diameter of $60 \mathrm{~mm}$ - SW060-L and of an extension piece of the tube with inner diameter of $60 \mathrm{~mm}-$ SW060-E.

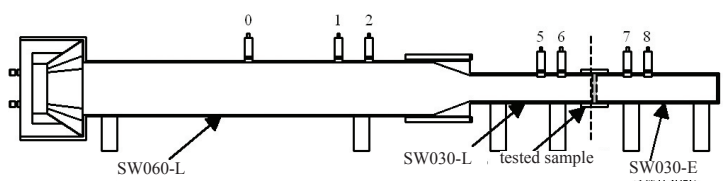

Legend: 0, 1, 2, 5, 6, 7, 8 mounting sockets for microphones

Fig. 9: The system for measuring the transmission loss $T L(1600 \mathrm{~Hz}$ to $6300 \mathrm{~Hz})[1]$.

The system for measuring the transmission loss (TL) (for the frequency bands of $1600 \mathrm{~Hz}$ to 6300 $\mathrm{Hz}$ ) is shown in Fig. 9. It is comprised of a tube with 


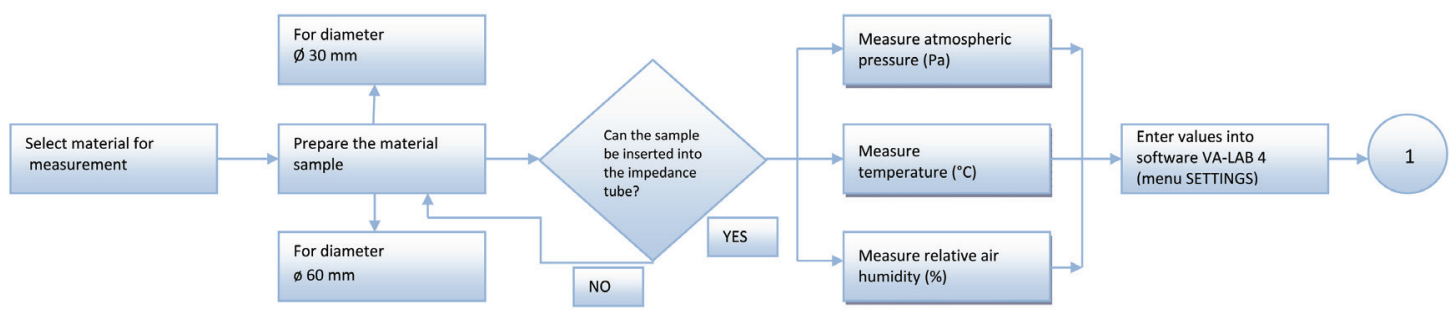

Fig. 2: Methodology for measuring selected acoustic descriptors [1].

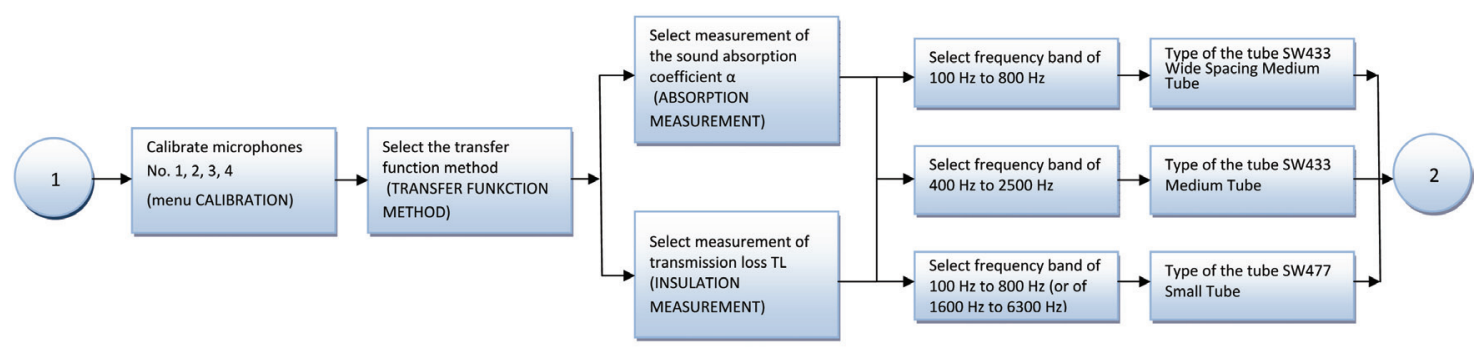

Fig. 3: Methodology for measuring selected acoustic descriptors (continued) [1].

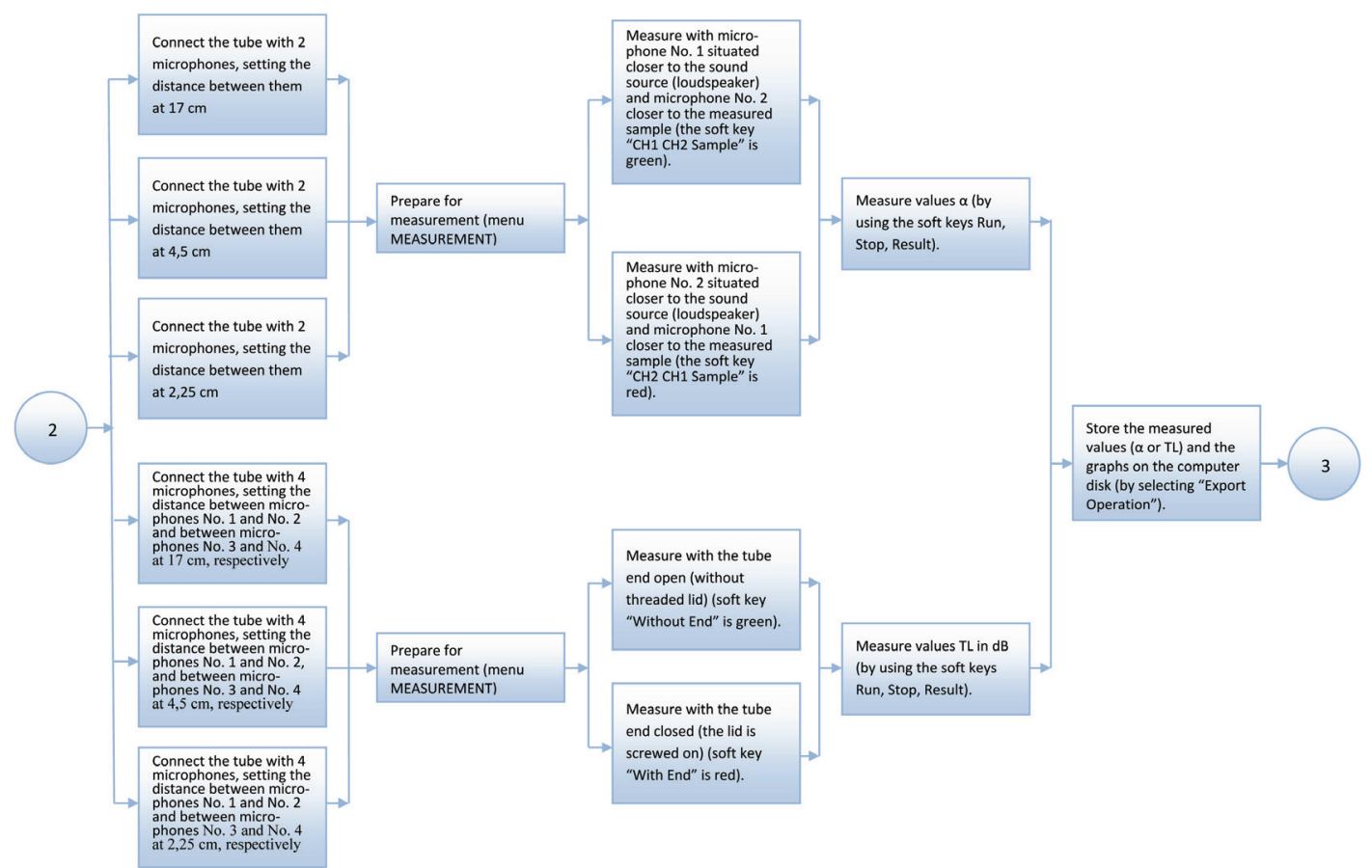

Fig. 4: Methodology for measuring selected acoustic descriptors (continued) [1].
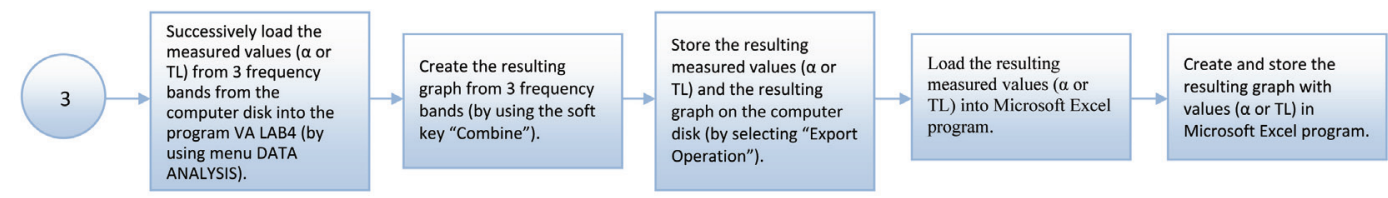

Fig. 5: Methodology for measuring selected acoustic descriptors (continued) [1]. 
inner diameter of $60 \mathrm{~mm}$ - SW060-L, of a tube with inner diameter of $30 \mathrm{~mm}$ - SW030-L and of an extension piece of the tube with inner diameter of 30 $\mathrm{mm}$ - SW030-E.

\subsection{Selection of Materials for the Experimental Part}

The selected acoustic descriptors (the sound absorption coefficient $a$, the transmission loss $T L$ ) were measured for the following acoustic materials, which are currently in process of development:

- Ekomolitan (Fig. 10) [2,3,5]

- Recycled rubber (Fig. 11) [2,3,6]

Measurement were also carried out, for comparison, for the material Nobasil (Fig. 12), which is a component part of various sandwich structures of noise walls (barriers).

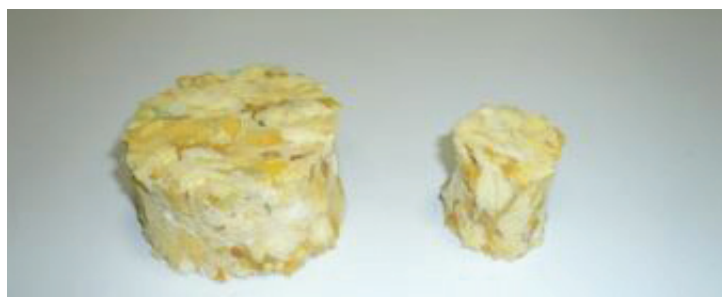

Fig. 10: Ekomolitan [1].

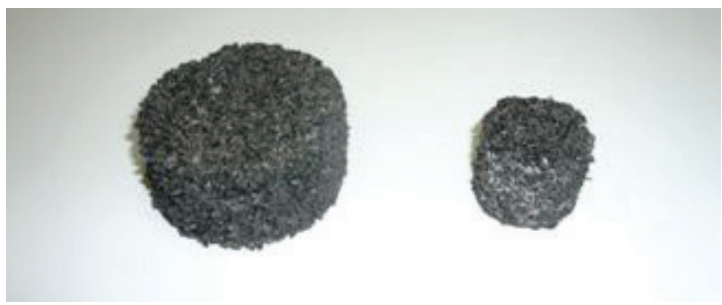

Fig. 11: Recycled rubber [1].

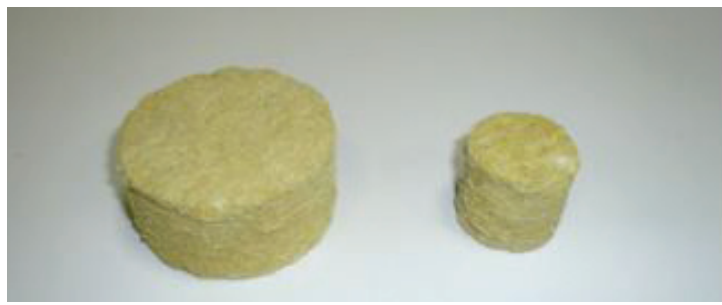

Fig. 12: Nobasil [1].
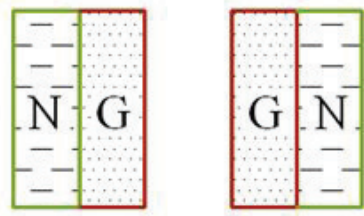

a)
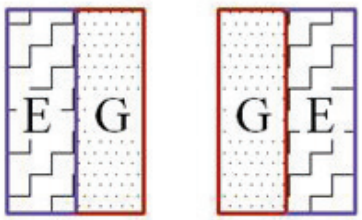

b)
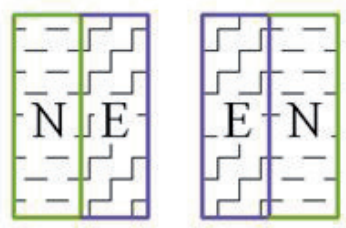

c)

Legend: N - Nobasil, G - recycled rubber, E-Ekomolitan Fig. 13: Two-layer sandwich samples [1].
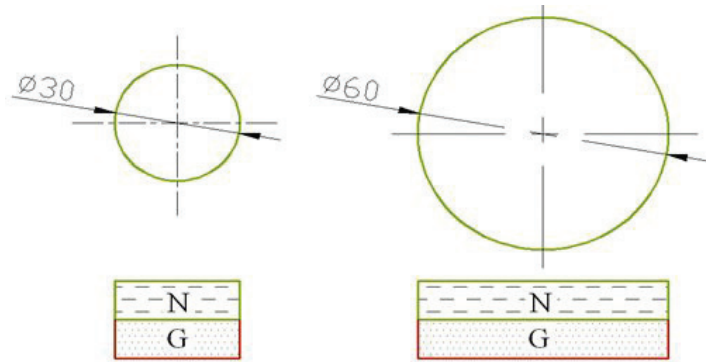

Fig. 14: Dimensions of the two-layer test sample [1].

\subsection{Preparation of Test Samples}

The test samples of the two-layer sandwich absorbers were prepared in various combinations of materials, such as Ekomolitan, Nobasil and recycled rubber (Figs. 13. a 14.).

Dimensions of the test sample:

\subsection{The Measured Values of the Sound Absorption Coef- ficient and of the Transmission Loss}

This part of the paper presents outputs from the measurement of the sound absorption coefficient carried out for a two-layer sandwich test sample composed of $2 \mathrm{~cm}$ thick recycled rubber positioned closer to the sound source and of $2 \mathrm{~cm}$ thick Ekomolitan positioned at the end (Fig. 15.) [1], as well as outputs from the measurement of transmission loss for a two-layer sandwich having the same material composition (Fig. 16.) [1]. 


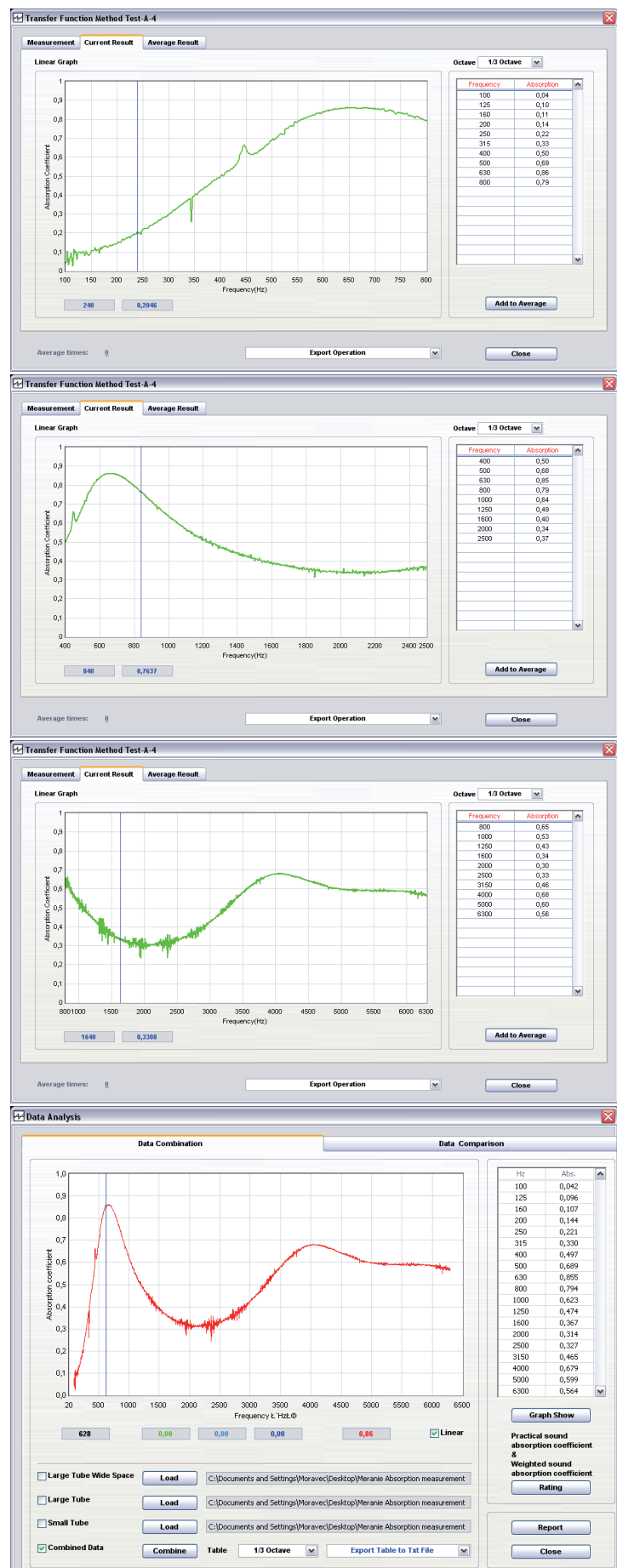

Fig. 15: Display of the sound absorption coefficient for a twolayer material, composed of $2 \mathrm{~cm}$ thick recycled rubber positioned closer to the sound source and of $2 \mathrm{~cm}$ thick Ekomolitan positioned at the end.

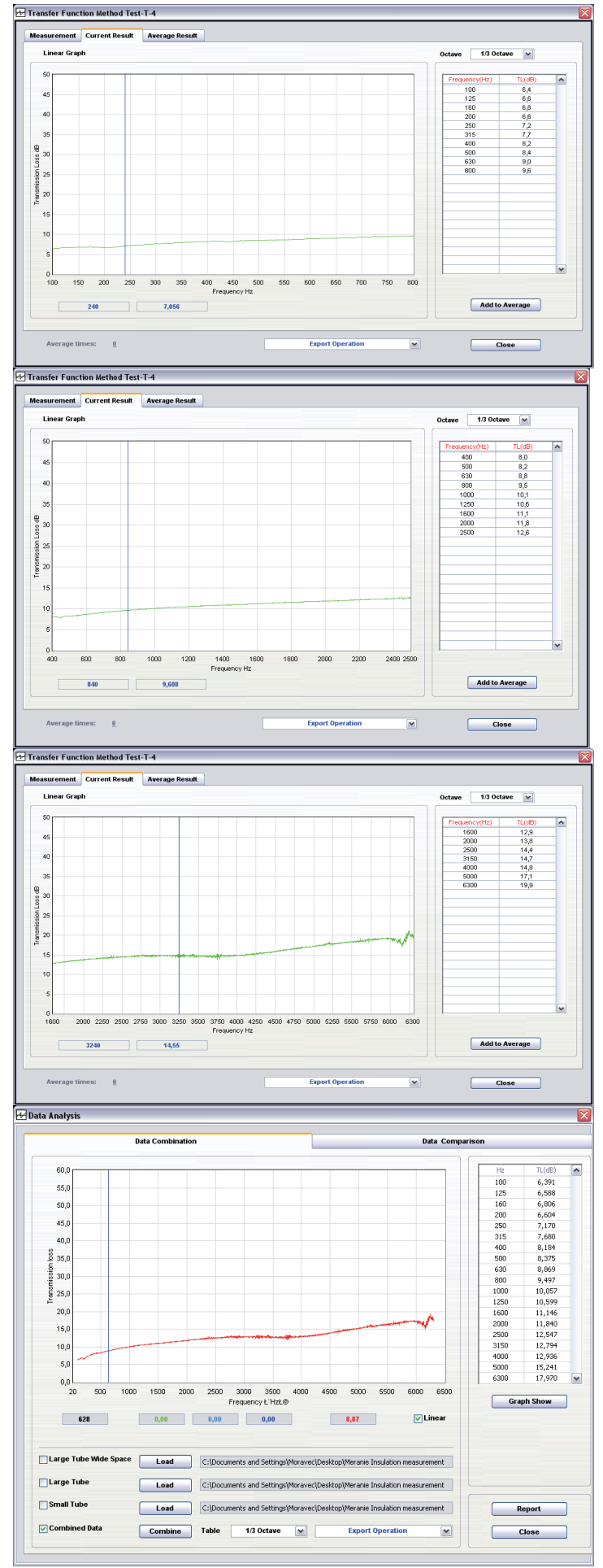

Fig. 16: Display of the transmission loss for a two-layer material, composed of $2 \mathrm{~cm}$ thick recycled rubber positioned closer to the sound source and of $2 \mathrm{~cm}$ thick Ekomolitan positioned at the end. 


\section{Conclusion - Evaluation of Measured Values}

The sound absorption coefficient (a) is a dimensionless number varying from 0 to 1 . The closer is the measured value to 1 or is equal to 1 , the sample of the measured absorber, and thus the absorber itself, will have a better (higher) sound absorption $[4,10,14]$

We have also measured the transmission loss ( $T L$ ). It is a value in $\mathrm{dB}$, based on the ratio of the sound wave incident at the front side of the acoustically absorbing material to the sound waves transmitted from the rear side. $T L$ represents the sound damping properties of the material, i.e. the higher that value is, the more efficient is the damping of the sound.

The authors have measured the coefficient of sound absorption ( $\mathrm{a}$ ) and the transmission loss ( $\mathrm{TL}$ ) for various combinations of two-layer sandwich

Table 1: The values of the materials with thickness of $4 \mathrm{~cm}$. absorbers composed of materials such as Ekomolitan, recycled rubber and Nobasil. Table 1. includes the measured values of descriptors.

The frequency spectrum of noise caused by transportation reaches its maximum in the frequency range of $500 \mathrm{~Hz}$ to $1500 \mathrm{~Hz}$, and the most intensive noise is caused at the frequency of 1000 $\mathrm{Hz}[10,11,12]$.

Noise walls (barriers) are often constructed as noise panels with a supporting frame using sandwich absorbers. For the purpose of the thesis, samples representing a sandwich composed of materials such as recycled rubber, Nobasil and Ekomolitan were made. The arrangement of individual layers of the sandwich was different. Measurements have been carried out for two-layer sandwiches. (Fig.17 and Fig. 18).

It follows from the measured values of the sound absorption coefficient of the sand-wich absorbers that the sequence of individual layers (of utilized

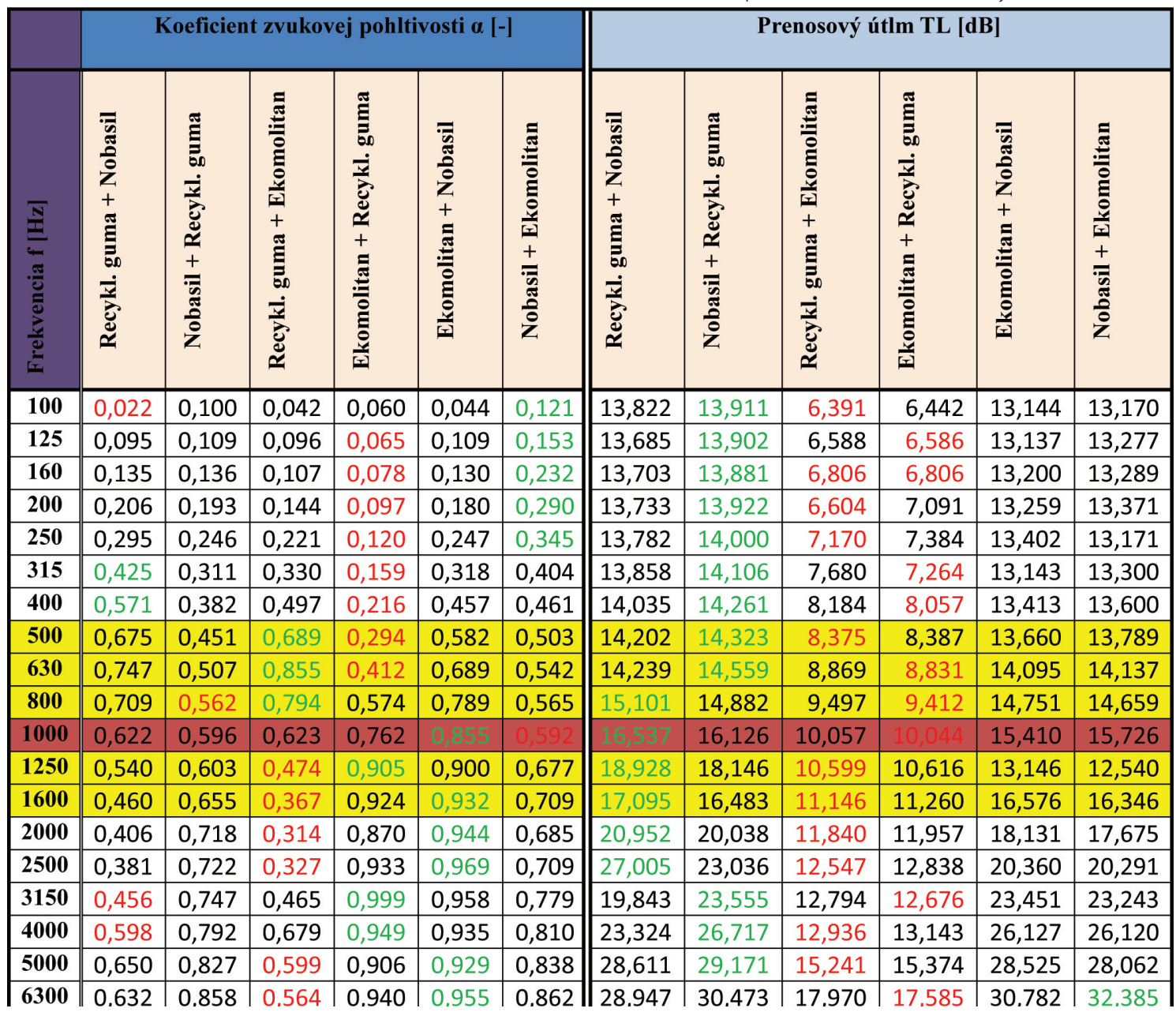


materials) is of crucial importance. The sequence of the sandwich layers of the measured materials, starting from the noise source (for the frequency of $1000 \mathrm{~Hz}$ ), is recommended as follows:

\section{- Ekomolitan + Nobasil,}

- Ekomolitan + recycled rubber,

- Recycled rubber + Nobasil.

It can be stated on the basis of the measured values of transmission loss of the sand-wich absorbers (Fig. 18.) that the sequence of individual layers of materials utilized in the sandwich is also of crucial importance.

The sequence of the sandwich layers of the measured materials utilized for two-layer sandwiches, starting from the noise source, is recommended as follows:

\section{- Recycled rubber + Nobasil, \\ - Recycled rubber + Ekomolitan, \\ - Nobasil + Ekomolitan.}

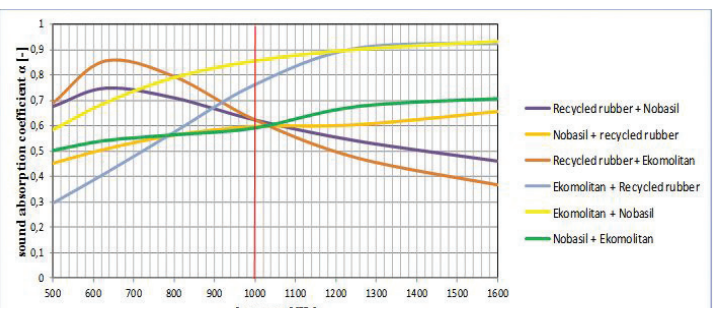

Fig. 17: Sound absorption coefficient of two-layer sandwiches (total thickness of the sandwiches: $4 \mathrm{~cm}$ ) [1].

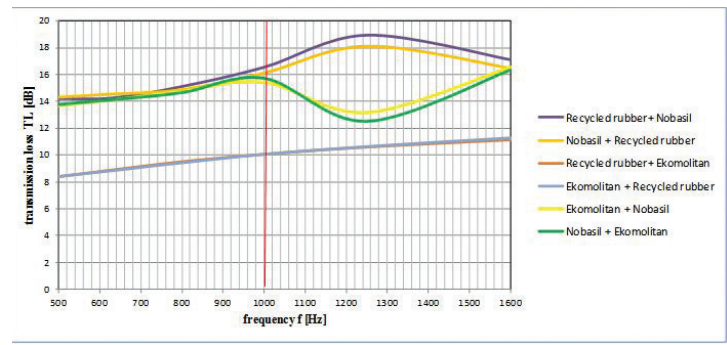

Fig. 18: Transmission loss of two-layer sandwich absorbers (total thickness of the sandwiches: $4 \mathrm{~cm}$ ) [1].

\section{Acknowledge}

This paper has been prepared on the basis of the research project APVV-0176-07, KEGA 3/7422/09.

\section{References}

[1] BADIDA, M. - LUMNITZER, E. - BARTKO, L.: Možnosti znižovania dopravného hluku. Košice: Elfa, 2011. 303 s. ISBN 978-80-8086-181-0.

[2] BADIDA, M. - LUMNITZER, E. - FIL'O, M. - BIL'OVÁ, M.: Deter- mination of the uncertainties of noise measurements. In: Annals of the Oradea University: Faculty of management and technological engineering. Vol. 7, 2008. p. 64-72. ISSN 1583-0691.

[3] BADIDA, M. - LUMNITZER, E. - ROMANOVÁ, M.: The application of recycled materials for products that provide noise reduction in living and working environment. In: Acta Acoustica United with Acoustic. Vol. 92. Stuttgart: Hirze Verlag, 2006. p. 108. ISSN 1610-1928.

[4] BADIDA, M. - LUMNITZER, E. - BILOVÁ, M.: The Usage of Dynamic Visualization by Industrial Noise Source Analysis. In: Journal Acta Mechanica Slovaca, No.1/2009, Vol. 13, SjF TUKE Košice, pp. 20-25, ISSN 1335-2393

[5] LUMNITZER, E., BADIDA, M. LIPTAI, P.: Využitie recyklantov z autovrakov pri návrhu protihlukových opatrení v lomoch. In: TOP 2010: technika ochrany prostredia, 15-17.jún 2010, Častá - Papiernička, Bratislava. s. 251-256. ISBN 978-80970438-0-3

[6] MATEL, F. - OCHOCOVÁ, R. - BADIDA, M. - LUMNITZER, E. Kompaktné prvky z gumárenského recyklátu vyrobené technológiou mikrovlnného ohrevu. Úrad Priemyselného Vlastníctva SR, Banská Bystrica, 2003.

[7] NEUBERGOVÁ, K.: Ekologické aspekty dopravy. Praha: ČVUT, 2005. 163 s. ISBN 80-01-003131-4.

[8] STN EN ISO 10534-1: 1996, Akustika. Určovanie koeficienta zvukovej pohltivosti a akustickej impedancie $v$ impedančných trubiciach. Čast' 1: Metóda použitia stojatej viny.

[9] STN EN ISO 10534-2: 1998, Akustika. Určovanie koeficienta zvukovej pohltivosti a akustickej impedancie $\vee$ impedančných trubiciach. Čast' 2: Metóda transformačnej funkcie.

[10] STN EN 1793-1: 1997, Zariadenia na zníženie hluku z cestnej dopravy. Skúšobné metódy určovania akustických vlastností. Čast' 1: Určenie zvukovej pohltivosti.

[1 1] STN EN 1793-2: 1997, Zariadenia na zníženie hluku z cestnej dopravy. Skúšobné metódy určovania akustických vlastností. Čast' 2: Určenie vzduchovej nepriezvučnosti.

[12] STN EN 1793-3: 1997, Zariadenia na zníženie hluku z cestnej dopravy. Skúšobné metódy určovania akustických vlastností. Čast' 3: Normalizované spektrum dopravného hluku.

[13] Smernica Rady EÚ zo 6. februára 1970 o aproximácii právnych predpisov členských štátov o prípustnej hladine hluku a o výfukových systémoch motorových vozidiel. [online] [cit 2010-11-21]. Dostupné na internete: http://eur-lex.europa.eu/LexUriServ/LexUriServ. do?uri=CELEX:31970L0157:sk:NOT

[14] Ministerstvo dopravy, pôšt a telekomunikácií SR. Použitie, kvalita a systém hodnotenia protihlukových stien. Účinnost' od: 01-12-11 